\title{
CNTNAP1 Gene
}

National Cancer Institute

\section{Source}

National Cancer Institute. CNTNAP1 Gene. NCI Thesaurus. Code C24304.

This gene plays a role in brain signal transduction, and may be involved in cellular adhesion. 